\title{
ICT CAPACITY BUILDING: A CRITICAL DISCOURSE ANALYSIS OF RWANDAN POLICIES FROM HIGHER EDUCATION PERSPECTIVE
}

JeanClaude Byungura [byungura@dsv.su.se],Henrik.Hansson [hhansson@dsv.su.se],Stockholm University, DSV [http:/ / dsv.su.se], Sweden, Kamuzinzi Masengesho [kamuzinzim@gmail.com], University of Rwanda [http://www.cass.ur.ac.rw], Thashmee Karunaratne [thasmee@dsv.su.se], Stockholm University, DSV, Sweden

\begin{abstract}
With the development of technology in the $21^{\text {st }}$ Century, education systems attempt to integrate technology-based tools to improve experiences in pedagogy and administration. It is becoming increasingly prominent to build human and ICT infrastructure capacities at universities from policy to implementation level. Using a critical discourse analysis, this study investigates the articulation of ICT capacity building strategies from both national and institutional ICT policies in Rwanda, focusing on the higher education. Eleven policy documents were collected and deeply analyzed to understand which claims of ICT capacity building are made. The analysis shows that strategies for building ICT capacities are evidently observed from national level policies and only in two institutional policies (KIST and NUR). Among 25 components of ICT capacity building used, the ones related to human capacity are not plainly described. Additionally, neither national nor institutional policy documents include the creation of financial schemes for students to acquire ICT tools whilst learners are key stakeholders. Although there is some translation of ICT capacity building strategies from national to some institutional policies, planning for motivation and provision of incentives to innovators is not stated in any of the institutional policies and this is a key to effective technology integration.
\end{abstract}

\section{Abstract in French}

Avec le développement et la prolifération des nouvelles technologies de l'information au 21eme siècle, beaucoup des systèmes éducatifs tentent d'intégrer ces nouveaux instruments dans l'amélioration de l'enseignement-apprentissage et l'administration. Dans des universités, Il devient de plus en plus important de renforcer les capacités humaines et de l'infrastructure en terme des TIC, du niveau de la politique ainsi que de la mise en œuvre. Basée sur une analyse critique de discours, cet article examine l'articulation entre les stratégies nationales de développement des nouvelles technologies de l'information et les politiques subséquentes développées par les institutions d'enseignement supérieurs au Rwanda. Douze documents de politique guidant le développement des nouvelles technologies de l'information ont été analysés pour en inférer les capacités institutionnelles visées. L'étude montre que les capacités de base en nouvelles technologies de communication et de l'information sont clairement mises en évidence dans les politiques nationales, mais ne transparaissent que dans deux documents institutionnelles analysées (KIST et UNR). Parmi les 25 composantes clés du développement des nouvelles technologies de l'information, celles en rapport avec le développement des capacités humaines ne sont pas suffisamment mis en évidence dans les documents analysés. On remarque également que ni les politiques nationales, ni celles développées à l'échelle institutionnelle ne mentionnent la création d'un système de financement permettant aux étudiants d'accéder plus facilement aux outils informatiques leur permettant d'utiliser ces nouvelles technologies. En outre, on remarque qu'aucun de ces documents guides ne font référence à des mesures incitatives encourageant des personnes innovantes à s'impliquer à fond dans la promotion de nouvelles technologies de la communication et de l'information dans l'enseignement supérieur. 
Keywords: ICT Capacity building, ICT policies, Higher education system, Technology integration, Critical Discourse Analysis.

\section{Introduction}

The introduction of computers in everyday life has dramatically affected all sectors of activity including the education systems. Since the introduction of the Internet and World Wide Web, Governments and institutions of higher learning have invested significantly in projects to build Information and Communication Technology (ICT) capacities with the aim of promoting technology integration in education (Jowi, 2009; Romeo, Lloyd, \& Downes, 2012). Basically, ICT is no longer used only for educational administration but also in the whole pedagogical process.

The integration of ICT in education requires salient ICT capacities. Thus, building ICT capacity is a keystone that must be included in different ICT policies to inform stakeholders. For some authors, even if there are significant ICT policies, the integration of ICT in education is still a complex process (Tondeur et al., 2008; Goktas, Yildirim, \& Yildirim, 2009; Nachmias et al., 2004). Being considered as vital resource, ICT capacities must be planned, acquired and maintained regularly as stated in the institutional policies.

With recognizable efforts by countries in the developing world to drive a change from traditional to digital education, Al-Yaseen et al. (2012) and Salmon (2005) argue that sophisticated e-learning systems have been implemented in universities, though some have not been so successful to meet stakeholders' needs. A study by Gary et al. (2011) shows that the nature of failure of ICT integration in education arises when designing ICT related policies. Hence, the strategic planning of ICT capacity building should start at the very beginning stages of policy design and formulation by including all possible relevant ICT strategies.

Despite huge investments in Rwandan higher education sector for procuring ICT resources and digital skills development, there have been always assertions of a slow technology uptake. This means that the value addition of technology is not seemingly perceived. The Rwandan Ministry of Education drafted an ICT in Education Policy in 2008 which states clearly that the mission of the education sector is: "Creating a shared understanding for integrating ICT at all educational institutions, at all levels, to support the development of better teaching and learning to equip students and learners with $21^{\text {st }}$ skills" (Ministry of Education, 2008). Thus, public and private higher learning institutions in Rwanda are advised to develop their local ICT policies with an inspiration from the above national policy.

Some scholars conducted studies on policies related to technology integration more specifically with focus on European and American higher education systems (Valcke, 2004; Jordan, 2011; Lloyd, 2008; Freeman, 2014; Kozma, 2008). Hence, evidences are still lacking especially in terms of how ICT capacity building strategies are stated in policies of higher education system from a developing country context. The purpose of this study is to understand the extent to which ICT policies, in relation to the higher education system in Rwanda, assert strategies for ICT capacity building. The study evaluates both national and institutional level policies and both human and infrastructure capacities are taken into consideration for the discourse analysis. The study is thus, guided by the following research question: (a) What strategies of ICT capacity building are asserted by Rwandan ICT policies related to higher education? (b) To what extent are these strategies clearly emphasized for effective guidance in implementing technology in the new merged University of Rwanda? 


\section{Literature review}

The discovery of the power of technology for the American education systems, came up with a recommendation for reformulating strategies and master plans to include ICT aspects (Daniel, 1996). Considering the importance of technology in driving innovative change in education, developed countries, in particular, have suddenly incorporated technology-based strategies in their traditional policies. This innovation trend was not noticed by developing countries until late 1990s. Since then, developing countries adopted the revolutionized western policies (Phillips \& Ochs, 2004). The policy borrowing trend has created complexity in implementing technology in local contexts of African colleges and universities. This is because strategies that brought successful practices in developed countries are not taken for granted in the local contexts. Hence, specific strategies for building different ICT capacities have to be tailored with reference to the country and institutional context.

\section{Strategic policy versus operational policy in education: technology perspective}

The formulation of institutional level policy is inspired by national policies. However, ICT policies can be formulated at strategic level and operational level. Strategic ICT policies are those drafted at national level to provide national guidance in terms of integrating ICT in teaching, learning and administration at all education levels (Kozma \& Voogt, 2003; Means \& Olson, 1995). The second category of ICT in education policies includes those local policies assisting educational institutions to realize the national vision stipulated in strategic policies. These are called Operational Policies (Kozma, 2005; Nachmias et al., 2004; Tondeur et al., 2008) and are described as action plans, programs or guidelines that consist of schools' ICT infrastructure development projects, Teachers' training programs, technical support and innovative curriculum plans. Both strategic and operational policies should be holistically tied together for the overall country's educational vision.

More particularly in Rwanda, national level policies exist for different cross-sectorial nature and institutions are requested to draft their own ICT related policies by including their specific local innovation needs to be addressed. A number of policies such as Vision 2020, NICI Plan, and the recently Smart Rwanda are the examples of national level policies.

In either of policies described above, policy-makers must always ensure that the strategies of ICT capacity building are clearly defined. This is one way of guaranteeing that ICT is effectively integrated in education as planned, otherwise this implementation is far from being materialized.

\section{ICT policies and technology uptake in Rwandan higher education context}

With the country's vision 2020, the leading national policy document, the country envisions to become a middle income. To achieve this, the government claims that ICT is a key engine for transforming its economy through developing the required human capacities through higher education as one of the key pillars (NICI Plan 2011-015). The country's pace on building a national ICT infrastructure is remarkably noticeable when it comes to supporting education systems. The most funding for ICT integration in education is from bilateral and multilateral cooperation mostly the African Development Bank, the European Commission, SIDA, DFID and the World Bank.

From the inspiration of the national vision 2020 program, different policy documents related to ICT in education have been drafted to guide the implementation of ICT projects in different sectors including the tertiary education. Within the same framework, the Government of Rwanda (2000) created the national ICT master plan entitled National Information and Communication Infrastructure (NICI). The NICI plan's core value is to promote ICT integration as strategy to 
promote innovation in service delivery. From the education perspective, NICI plan posits that integration of ICT is a key strategy for socio-economic development and one of its objectives is to transform the education system through an effective technology integration. Following the translation of policies from national to institutional level, the NICI Plan was used in 2010 to develop a sub-plan of the ICT in Education policy under the mandate of the Ministry of Education (Farrell, 2007). Hence, strategies and action plans have been designed to support the process of ICT capacity building for technology integration in education, although a little emphasis on tertiary education is noticed. It is then from the national policies that all higher learning institutions in Rwanda are guided when developing ICT policies and ICT master plans that particularly inform how their specific visions and mandates will be realized.

In line with improving the use of ICT resources in higher education, there has been a reform that merged all public universities and institutes to form one University of Rwanda (Official Gazette no 38 of 23/09/2013). Despite this institutional restructuring, while conducting this research, all the ICT related policies of the former universities have been still into use as guidance for technology integration. In this study, these policy documents serve as data source to understand their statements about building different ICT capacities that should enable the university's innovation in pedagogy and administrative services.

Although the national policies seem to be generally quite well developed and clearly informative on how ICT could be integrated in education, the current rate of adoption and use of technology in teaching, learning and administration at University of Rwanda is still questionable by different stakeholders. Hence, institutional level policies are mostly raised as one of the factors contributing to such a failure in integrating technology.

\section{Conceptual analysis framework}

\section{ICT Capacity building for open and distance education}

The potential value of ICT on the improvement of distance education is still not perceived in developing countries as compared to the developed world. Lack of clear strategic policies for ICT capacity building are always deemed to be the root causes of this failure. Capacity building can be understood as a process of developing and strengthening the abilities of human and infrastructure resources for a specific project. For a successful integration of ICT in education, several variables must be interlinked to form a strong implementation framework (Aczel, Peake, \& Hardy, 2008; Akbaba-Altun, 2006). It requires primarily some types of digital skills for different involved stakeholders (mainly teachers, students, administrators and policy-makers). After that, technological infrastructure, organizational and pedagogical structures are planned and implemented. Hence, the above set of requirements, though not exhaustive, are achieved through what can be termed as ICT capacity building program (Gevaert, 2012; Nachmias et al., 2004; UNESCO, 2011; Henderson, Bellis, Cerovac, \& Lancaster, 2013; Marshall \& Ruohonen, 1998). In general, the concept of capacity building in education covers various aspects ranging from training teachers, developing the digital contents, implementing basic ICT infrastructure (computers and networking) and putting in place well-designed local ICT policies.

A classification made by InfoDev (2010) on capacity building for ICT in education considers three main dimensions: Institutional, Instructional and Investment aspects. In the same viewpoint, several dimensions of ICT capacity building can be developed under each of the above three clusters. The related literature has been explored to further understand some of these indicators as discussed in the following section. 


\section{ICT capacity building: institutional perspective}

This aspect focuses on building capacities by creating partnerships and collaborations with external experts in ICT and the government, development of plans and policies to acquire ICT infrastructure (Kozma, 2008; Larson \& Murray, 2008; Nachmias et al., 2004; Marshall \& Ruohonen, 1998) and training of IT support personnel in advanced ICT skills (Nichols, 2008). This cluster includes also the development of digital skills for administrators and the creation of an awareness on the existing available ICT tools (Sife, Lwoga, \& Sanga, 2007; Bhuasiri, Xaymoungkhoun, Zo, Rho, \& Ciganek, 2012). The institutional cluster considers also the availability of adequate basic ICT resources as the building blocks for effective ICT integration (Goktas, Yildirim, \& Yildirim, 2009; Keengwe, Kidd, \& Kyei-Blankson, 2009).

\section{ICT capacity building: instructional perspective}

This dimension put an accent on building capacities that are related on pedagogical innovation (Owston, 2007; Owens, 2012). These include the development of ICT literacy among teachers (Ojo \& Awuah, 1998) and students (Kennedy, Judd, Churchward, Gray, \& Krause, 2008). In addition, it should go further by developing capacities for creating and managing digital contents (Bates, 2000; Govindasamy, 2001; Sun, Tsai, Finger, Chen, \& Yeh, 2008).

\section{ICT capacity building: investment perspective}

The investment dimension may include the creation of knowledge about how strategically the university can select the appropriate mixture of technological tools (InfoDev, 2010). At this stage, the university must have updated knowledge on the cost of selected technologies (Instructional technologies and basic ICT infrastructure). The investment cluster should also have plans for motivations and incentives for innovation champions and create financial schemes for the faculty and students to allow them acquire their own digital devices (Plessis \& Webb, 2012). Correspondingly, technology integration in education involves considerable investments in ICT infrastructure to ensure wide access, maintenance, functionality, compatibility and complementarity of educational technologies (Bates, 2001; Tanrikulu, Tugcu, \& Yilmaz, 2010).

Based on the above three clusters, a conceptual analysis framework has been theoretically proposed to help in understanding how policy documents related to ICT integration in Rwandan higher education claim to build a set of ICT capacities to support higher education institutions in Rwanda. The Figure 1 below illustrates 25 indicators for ICT capacity building clustered in three dimensions: 


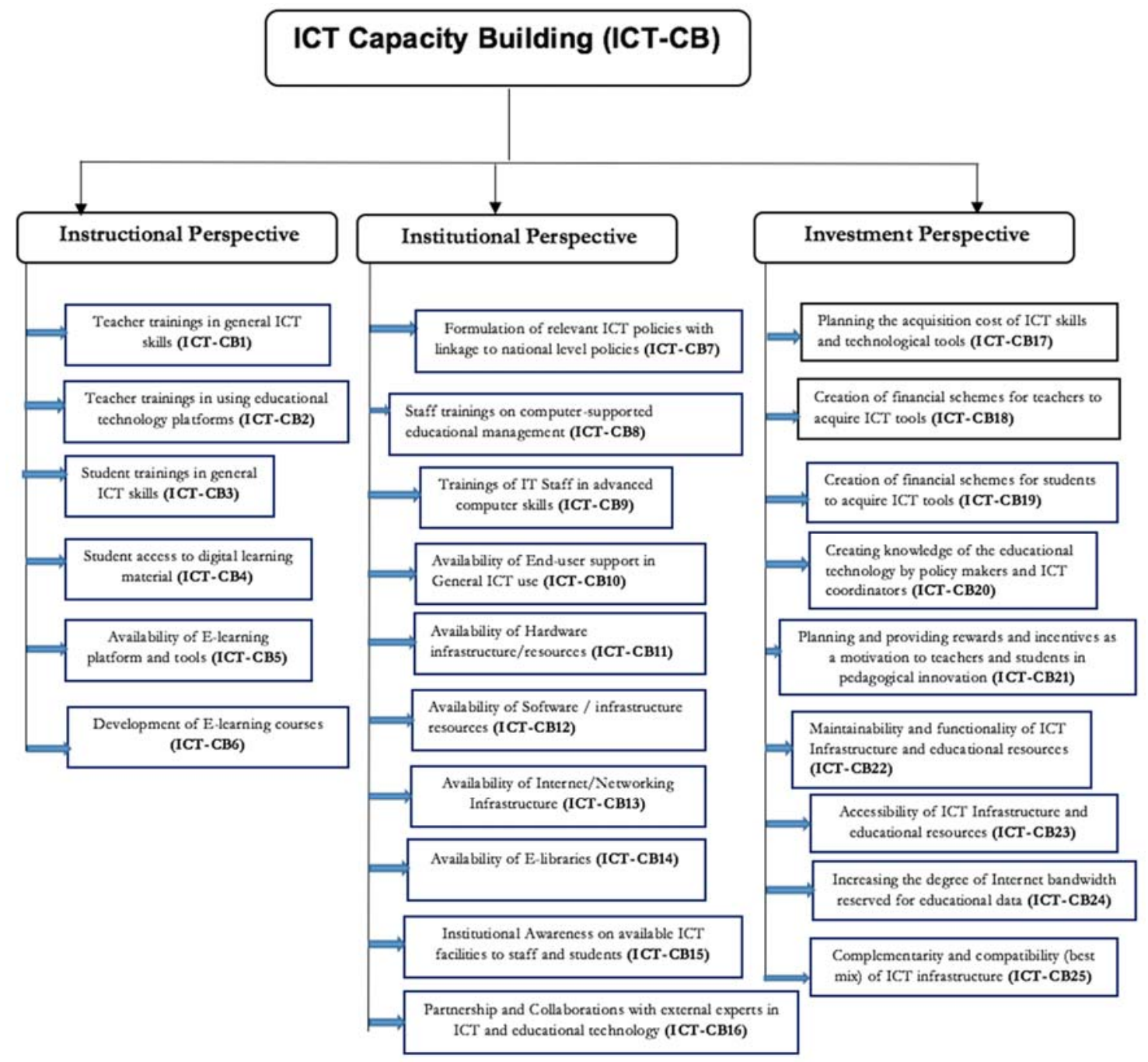

Figure 1. ICT Capacity Building framework: Three dimensions

\section{Method}

The methodology used for this study is a Critical Discourse Analysis (CDA), which is about the exploration of linguistics or semantics with the purpose of understanding the meaning (Cutting, 2002; Gee, 2005; Fairclough, 2013). The concept of discourse refers to a number of elements such as a policy, a historical monument, a political strategy or a narrative text and a speech (Wodak \& Meyer, 2009; van Dijk, 1998). According to van Dijk, discourse is seen as a multidimensional social phenomenon as it reflects

"linguistic (verbal, grammatical) object (meaningful sequences or words or sentences), an action (such as an assertion or a threat), a form of social interaction (like a conversation), a social practice (such as a lecture), a mental representation (a meaning, a mental model, an opinion, knowledge), an interactional or communicative event or activity (like a parliamentary debate), a cultural product (like a telenovela) or even an economic commodity that is being sold and bought (like a novel)".

By using the CDA, discourse analysts make their own position on a particular statement or a variable and then seek to understand and highlight a social phenomenon from a specific unit of discourse (van Dijk, 2009). The discourse analysis as a research tradition can be also used to 
explain the dynamics of exploration on a longitudinal basis such as the analysis of different policy documents (Social structure) or the interview transcriptions (Social interaction). Accordingly, the $\mathrm{CDA}$ is used in this study as a research approach that is methodologically based on the analysis of some documents related to ICT policies currently in place to support the integration of ICT in Rwandan higher education. The intention to use a Critical Discourse analysis approach for this study is to increase a deeper knowledge about the issue of ICT capacity building from the policy perspective.

In this study, the main unit of discourse is the text (ICT policy documents) and this is according to Brown and Yule (2008) the representation of such a discourse where the paradigm of ICT capacity building for higher education is explored. Within the framework of discourse analysis as a structural approach, this study will investigate the content of the policy while trying to understand ICT capacity building strategies stated by these documents. Therefore, CDA is used in this study to understand claims about ICT capacity building in the Rwandan ICT policies as a support to technology integration in higher education. With CDA as an approach to understanding the meaning from a language (text or verbal); policy documents have been collected from the Ministry of Education, the Ministry of Science and Technology and the University of Rwanda.

\section{Research design and document selection}

This is a qualitative study and the main source of data is the policy documents that are related to ICT strategies and master plans for Rwandan higher education sector. In total, 11 documents were collected from five institutions. Among these documents, 9 out of them were deeply analyzed while the remaining 2 (Rwanda Vision 2020 and National Science, Technology and Innovation Policy) were only used for reference and cross-checking to understand the degree of policy translation. These documents were selected because they either have a direct or indirect linkage to the process of building ICT capacities and integration of technology in education. Subsequently, a semantic criticism was undertaken by reading closely these policy documents in order to map every theme that has been stated in regard to building ICT capacities.

As the focus was on ICT policy documents related to higher education system, the sample was limited to the national and institutional policies that are linked to the new university of Rwanda. Prior to engaging in data collection and analysis steps, the literature on ICT integration and ICT capacity building in education has been conducted to form the base for determining variables of ICT capacity building (Figure 1) which were used during discourse analysis. 
ICT Capacity Building: A Critical Discourse Analysis of Rwandan Policies from Higher Education Perspective Jean Claude Byungura et al.

Table 1: List of analyzed policies

\begin{tabular}{|c|c|c|c|c|}
\hline No & Title of the Policy & Source/Owner & Policy Level & $\begin{array}{l}\text { Publication } \\
\text { Year }\end{array}$ \\
\hline 1 & Rwanda Vision 2020 & Office of the President & National Level & 2000 \\
\hline 2 & $\begin{array}{l}\text { Rwanda Science Technology } \\
\text { and Innovation Policy }\end{array}$ & Office of the President & National Level & 2006 \\
\hline 3 & $\begin{array}{l}\text { Rwanda ICT Strategic and } \\
\text { Action Plan (NICl-III) }\end{array}$ & $\begin{array}{l}\text { Rwanda Development } \\
\text { Board (RDB/ICT) }\end{array}$ & National Level & 2011 \\
\hline 4 & SMART RWANDA Master Plan & MYICT & National Level & 2015 \\
\hline 5 & Higher Education Policy & MINEDUC & National Level & 2008 \\
\hline 6 & ICT in Education Policy & MINEDUC & National Level & 2008 \\
\hline 7 & ICT Master Plan NUR & UR former NUR & $\begin{array}{l}\text { Institutional } \\
\text { Level }\end{array}$ & 2011 \\
\hline 8 & ICT Policy and Master Plan KIST & UR former KIST & $\begin{array}{l}\text { Institutional } \\
\text { Level }\end{array}$ & 2004 \\
\hline 9 & ICT Policy KIE & UR former KIE & $\begin{array}{l}\text { Institutional } \\
\text { Level }\end{array}$ & 2012 \\
\hline 10 & ICT Policy SFB & UR former SFB & $\begin{array}{l}\text { Institutional } \\
\text { Level }\end{array}$ & 2012 \\
\hline 11 & ICT Policy IZAE & UR former IZAE & $\begin{array}{l}\text { Institutional } \\
\text { Level }\end{array}$ & 2012 \\
\hline
\end{tabular}

\section{Procedures}

The data collection and analysis were done from April 2014 to July 2015. Different ICT policy documents were gathered from the institutions indicated in Table 1. Among the collected policies include the approved and drafts ones. The analysis went for each paragraph block with reference to each variable from the analysis framework. The aim was to discover the statements related to the ICT capacity building as a phenomenon under investigation.

\section{Results and discussion}

This study went through the above mentioned policies in Table 1 to investigate first whether there are statements about ICT capacity building strategies. Further on, the analysis went in deep to understand the extent to which building ICT capacities is emphasized with reference to indicators proposed in the conceptual framework and if there is any translation of strategies from national to institutional policies. Table 2 below is a matrix that summarizes the results from the analysis. 
Table 2: Matrix representing ICT capacity building strategies from document policies

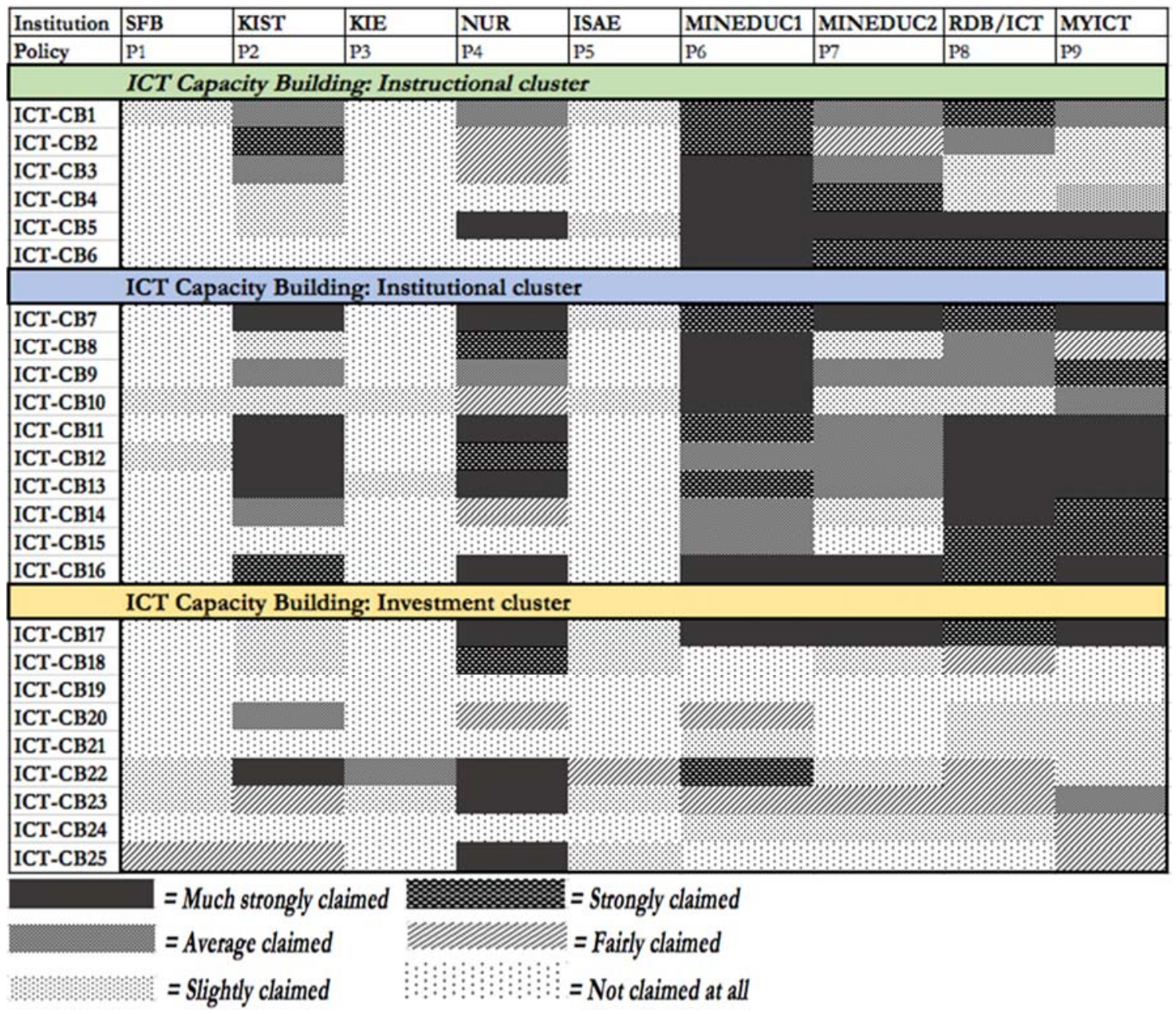

\section{Instructional cluster discourse}

From the Table 2, it can be observed that the instructional cluster includes 6 indicators from ICT-CB1 to ICTCB6. In this cluster, the analyzed policy documents indicate that the national level policies provide more elements that claim to build ICT capacities as compared to university policies. In addition, policies from the former KIST and NUR include some strategies for technology capacity building in this cluster as compared to the rest from others (SFB, ISAE and KIE). For example, the ICT policy from the former KIST informs about provision of teacher training in developing E-content and using educational technology platforms by claiming:

“... Objective: Build capacity to all academic staff in web based content development [p. 20] ... the institute will need to provide resources ...., as well as providing financial assistance for ICT education and training [p. 20] ... All existing institute staff will be trained in basic computer skills and other computer skill levels relevant to their jobs. [p. 20]” 
The same institution also planned and strategized how it will provide teacher training in general ICT skills (ICTCB1) as it can be observed from the extracts below:

"... It is the institute policy that all new staff to be recruited should be computer literate with minimum basic computer skills relevant to their jobs. All existing institute staff will be trained in basic computer skills and other computer skill levels relevant to their jobs. [p. 37]"

Some aspects of building ICT capacities are also emphasized by the former NUR ICT policy in some extracts. For example, for teacher and student trainings in ICT skills (ICT-CB1 and ICTCB2), the policy highlights that:

"The eleven principles of this doctrine are: ... G. Training of faculty, staff, and students is essential to take advantage of technology investments; ... G-1. Expand ICT training to address the needs of faculty and staff ... [p. 20]"

This institution claims also that it will build ICT capacities by availing access to E-learning platforms and tools (ICT-CB5):

"... Integrate the course management system (e.g., Moodle) with the student Information system through the use of a common directory service ... [p. 30]

... D-1. Enhance the interactive distance learning (IDL) classroom environment, providing the capability to deliver multiple concurrent academic courses at a distance. [...] as required to accommodate the increased number of academic courses tanght at a distance. [p. 15]."

Nevertheless, students access to digital learning materials (ICT-CB4) and development of Elearning courses (ICT-CB6) are slightly claimed only by KIST's policy. The perception here is that this may have impeded technology integration at these institutions as online courses are the core elements of e-learning systems as argued by scholars in this domain (Taylor \& Newton, 2012; Porter, Graham, Spring, \& Welch, 2014; Nachmias et al., 2004).

\section{Institutional cluster discourse}

From the analysis framework, this cluster includes 10 indicators that are related developing local guidelines and providing trainings for the support staff. The discourse analysis indicates that strategies for ICT capacity building in this area are claimed on an advanced level as compared to the instructional cluster. Examples of increased positive statements on building ICT capacities can be noticed on indicators such as ICTCB-7, ICTCB-11, ICTCB-13 and ICT-CB16. Like the instructional cluster, only NUR and KIST documents explain clearly these strategies while the rest from other universities are not explicitly well-defined. The following typical examples are extracted from policy documents from the former NUR:

“... Establish written policies and procedures for 'enterprise' issues related to information and communication technology (privacy, use, copyright, etc.). Publish these in a prominent location on the University website, making them readily available to the University community. [p. 10]

... Create hardware and software standards for personal computing and communication devices to improve integration between internal and external constituents, and leverage existing resources ... [p. 11]

H-1. Include wireless capabilities as an integral component of the network infrastructure. [p. 21] 
... Explore potential partnerships with businesses and vendors to create an Institutional experimental laboratory with current and leading edge equipment and technologies. This committee will consist of fifteen members, two-thirds of whom will be ICT professionals from business and community groups such as RDB-IT, MTN, TIGO, RURA, RwedNet, and Local District. [p. 10]”

For the former KIST, some extracts are also taken from its ICT policy and master plan in relation to the above mentioned indicators of ICT capacities:

"... The main purpose of a security policy is to inform users, staff and manager of their requirements for protecting technology and information assets. [p. 28]

... The institute will have at least one computer per 5 undergraduate students enrolled for undergraduate degrees and 1 computer per masters or PhD students. [p. 377 ... User-level Data Communication Services such as E-mail, Access to Internet, Internet/Intranet Services, which actually are major users of the low level network services. E-mail, Access to Internet services (WWW, FTP) requires specific applications software on the users' workstations. [D. 10]"

On the other hand, it has been also realized that no institutional policy has asserted the creation of awareness for the available ICT facilities (ICT-CB15) while all national policy documents have claimed this variable as a strategy to build ICT capacities.

\section{Investment Cluster discourse}

Results from the discourse analysis indicate that this is the least asserted cluster as many of its indicators score a low degree of appreciation. Only the former NUR heightened clearly on some of the investment's indicators in ICT capacities especially ICT-CB17, ICT-CB22, ICT-CB23 and ICT-CB25. Some extracts taken from the former NUR policy can confirm the above identified indicators:

“... E-2. Establish an ICT Initiative Advantage Fund (Initiative Fund) that will enable the institution to develop and implement multiyear information and communication technology fiscal plans and budgets for significant projects to enhance the campus wide information technology architecture ... [p. 16]

... Academic, administrative, and business operations require a current, reliable and secure computing and network environment ... [p. 21]

... C-3. Coordinate computer lab accessibility and operation throughout the institution, researching the availability of computer lab resources, the proliferation of labs on campus, and the need for up-to-date technology for general and specialized labs. [p. 13]

... B-3. Promote infrastructure/architecture software application principles to enhance interoperability and compatibility across systems. [D. 12]"

In the same cluster, all institutional policy documents do not claim the creation of financial schemes for students and teachers for enabling them acquire ICT tools (ICT-CB18, ICT-CB19) and the increase of internet bandwidth reserved for educational data (ICT-CB24); while these are the main factors for effective access and use of online learning management systems. Additionally, the planning of motivation and provision of incentives to innovators (ICT-CB24) are also not stated in any of the university policies. This has been argued by a number of scholars (Plessis \& Webb, 2012; Hernandez, Montaner, Sese, \& Urquizu, 2011) as a one of the significant 
factors that contribute to teachers and learners' degree of intention to use computer-supported tools in teaching and learning.

\section{Policy translation from national to institutional context}

As advocated by Kozma (2005), the broad guidelines and objectives from national level policies are contextualized by the institutional level policies to enable the operationalization of national programs. Therefore, some of the analyzed policies (KIE, IZAE and SFB) did not consider this translation and no clear relationship was found among their policies and the national level policies. The above institutional policies include only rules, regulations and procedures on the use of ICT facilities. Hence, they do not have any strategy or plan on how either human or infrastructure capacities related to ICT will be developed.

However, reading from the policy document from KIST for example, this translation from national to institutional context has been identified on some variables of ICT capacity building.

Taking an extract from the ICT in Education Policy document from the Ministry of Education

"... for successfully integrating ICT in education, curriculum revisions need to be continually conducted, along with training on ICT and ICT enabled teaching and learning. As ICT is a cross cutting tool, it not only sufficient to teach it as a subject, cross disciplinary instruction whereby ICT is integrated as a pedagogical tool for teaching and learning is encouraged [p. 22]"

It can be realized that the above rhetoric has been appropriately translated to the KIST ICT Policy and Master Plan as:

"... It is the institute policy that all new staff to be recruited should be computer literate with minimum basic computer skills relevant to their jobs. All existing institute staff will be trained in basic computer skills and other computer skill levels relevant to their jobs. [p. 37]”.

Another example is from NUR ICT policy developed by the former ICT Centre. It has been formulated in accordance with the Higher Education Policy, which plan to build ICT capacity by availing E-learning platforms and tools (ICT-CB5).

While the Higher Education Policy claims:

"... To support the introduction of learning laboratories to facilitate the production of materials for students to support the move from a didactic to student cantered pedagogy and enable the use of electronic resources. [p. 19]"

This same statement has been translated in NUR ICT policy as:

"... The successful use of technology in teaching and learning requires technology enhanced classrooms and instructional support services. [p. 4]"

and:

"D-3. Adopt multimedia conferencing software including a workgroup messaging system (groupware), to use with in-person traditional classes ... as well as bybrid classes and courses taught completely at a distance. [p. 15]" 
As mentioned earlier, discourses show that some university policies have clearly accommodated strategies from national level policies and this is an important policy structure to fulfil the country's vision in regard to technology integration. If well converted by institutions of higher learning, this is a positive sign on how these institutions try to implement national programs in terms of ICT capacity building. Hence, the current process of drafting a holistic ICT policy for the new merged university should consider making such a policy translation in order to reflect the overall nation vision on technology integration in higher education.

\section{Conclusion}

The aim of this study was to understand the extent to which Rwandan policies related to ICT in higher education system proclaim strategies for different ICT capacity building. In general, texts from analyzed national and institutional policies show that technology-based strategies for building ICT capacities are apparently revealed in national level policies but only in few institutional level policies (See the matrix Table 2). From the institutional policy viewpoint, five policies have been critically analyzed to find out how statements about ICT capacity building strategies are considerably articulated. With reference to indicators used for analysis, declarations of building ICT capacity are moderately articulated in only 2 out of 5 institutional policies (NUR and KIST).

All the 25 indicators of ICT capacity building used in this study are not clearly described at the same level in the analyzed policy documents. Therefore, ICT infrastructure (ICT-CB11, ICTCB12 \& ICT-CB13) and the creation of partnership (ICT-CB16) with experts are extremely stated while there is a noticeable low declaration of human capacity development strategies (ICTCB1, ICT-CB2, ICT-CB3, ICT-CB8 \& ICT-CB9) and formulation of local policies (ICT-CB7) to support technology integration process. It has been also revealed that neither national nor institutional policy document claims the creation of financial schemes for students (ICT-CB19) to acquire ICT tools. However, this is a bottleneck for ICT integration in higher education in particular as learners are key stakeholders for the effective integration of ICT. The university local policies should include strategies about financial schemes to support students to acquire technological tools. Although teachers may be well equipped with skills and available ICT infrastructure; but if learners do not have means to interact with teachers, peers or e-content in a connectivism learning mode (Siemens, 2014), then learning process becomes chaotic and more complex. Also apparent, the planning of provision for incentives as motivation to innovators (ICT-CB21) is also not declared in any of the institutional policies analyzed. As far as innovative instructional technology is concerned, there are also no clear strategies on how ICT can be integrated to drive innovative change in aspects such as developing e-learning courses, availing digital contents and training of instructional technologists.

It has been surprisingly perceived that only two documents from former KIST and NUR can be qualified as policies while the rest from KIE, IZAE and SFB seem to be only rules and regulations on the use of ICT facilities available at campuses. The later documents do not really inform about goals, strategies and programs that will be supporting the university in regard to building ICT capacities to integrate technology. But again, while NUR and KIST policies and master plans are well clear about these goals for some indicators, they seem to be outdated and there was no recent revised copy that should attempt to address the current rapid change in technology. Furthermore, all institutional policies are still being used by the colleges of the new University of Rwanda. Hence, this new university should consider crafting its holistic ICT Policy and Mast Plan that could reflect reliably its new mission and vision. In addition to this, based on these institutional level policies, each college should also create a specific E-learning policy that will mainly focus on innovative pedagogy for their specific visions and teaching programs. 
Subsequently, having well drafted clear policies is not enough to ensure effective integration of ICT in educational activities. Thus the University of Rwanda should set up mechanisms of operationalization and implementation of these policies. Periodic monitoring, follow up and evaluation of policy implementation at all departments and colleges are also crucial for identifying any single deviation at the early stage. This is due to the fact that, for some universities such as NUR and KIST, they had well crafted ICT policies but still the integration of technology in teaching and learning and building related capacities have been still questionable by different stakeholders. The University of Rwanda should adopt the culture of regular review and update of its ICT Policy and Master plan as this seems to be the case for the national guiding policies. From the country level, NICI Plan and SMART Rwanda are the new policies that reflect new technology and innovation aspects.

For this study, the list of identified indicators of ICT capacity building is not exhaustive and thus, further studies should be conducted to uncover new additional indicators. Afterward, this study was limited to the identification of strategies for ICT capacity building in Rwandan policies related to higher education. Therefore, further study is required to assess the state of building ICT capacities at University of Rwanda. A further investigation is also needed to explore the extent to which technology has been integrated so far and challenges, if any, that are faced by actors during the integration process at University of Rwanda or other similar higher learning institutions in the region.

\section{References}

1. Aczel, J. C., Peake, S. R., \& Hardy, P. (2008). Designing capacity-building in e-learning expertise: Challenges and strategies. Computers \& Education, 50(2), 499-510.

2. Akbaba-Altun, S. (2006). Complexity of integrating computer technologies into education in Turkey. Journal of Educational Technology \& Society, 9(1), 176-187.

3. Al-Yaseen, H., Hourani, M., \& Al-Jaghoub, S. (2012). Success and Failure of e-Learning Projects: Alignment of Vision and Reality, Change and Culture. Journal of Emerging Trends in Computing and Information Sciences, 3(2), 277-284.

4. Bates, A. W. (2000). Managing Technological Change: Strategies for college and university leaders. San Francisco: Jossey-Bass.

5. Bates, T. (2001). The continuing evolution of ICT capacity: The implications for education. In F. Glen (Ed.), The changing faces of virtual education (pp. 29-46). COL. Retrieved from http://oasis.col.org/handle/11599/39

6. Bhuasiri, W., Xaymoungkhoun, O., Zo, H., Rho, J. J., \& Ciganek, A. P. (2012). Critical success factors for e-learning in developing countries: A comparative analysis between ICT experts and faculty. Computers \& Education, 58(2), 843-855.

7. Brown, G. \& Yule, G. (2008). Discourse analysis. Cambridge University Press.

8. Cutting, J. (2002). Pragmatics and discourse: A resource book for students. Abingdon: Routledge.

9. Daniel, J. S. (1996). Mega-universities and knowledge media: Technology strategies for higher education. Psychology Press.

10. Fairclough, N. (2013). Critical discourse analysis: The critical study of language. Routledge.

11. Farrell, G. (2007). Survey of ICT and Education in Africa: Rwanda Country Report. Retrieved from https://www.infodev.org/infodev-files/resource/InfodevDocuments_423.pdf 
12. Freeman, B. (2014). Benchmarking Australian and New Zealand university meta-policy in an increasingly regulated tertiary environment. Journal of Higher Education Policy and Management, 36(1), 74-87.

13. Gee, J. P. (2005). An introduction to discourse analysis theory and method (2 ${ }^{\text {nd }}$ ed.). London: Routledge.

14. Gevaert, R. (2012). A sustainable model for ICT capacity building in developing countries. Proceedings of the $26^{\text {th }}$ International Conference on Large Installation System Administration: Strategies, Tools, and Techniques. 123-134. USENIX Association.

15. Goktas, Y., Yildirim, S., \& Yildirim, Z. (2009). Main barriers and possible enablers of ICTs integration into pre-service teacher education programs. Journal of Educational Technology \& Society, 12(1), 193-204.

16. Government of Rwanda (2013) Low no 71/2013 of 10/09/2013 establishing the University of Rwanda and determining its mission, powers, organization and functioning, Official Gazette no 38 of 23/09/2013. (pp.34-54). Retrieved on 17 August 2015 from http://www.mineduc.gov.rw/fileadmin/user_upload/Laws_UR_and_HEC-2.pdf

17. Govindasamy, T. (2001). Successful implementation of e-learning: Pedagogical considerations. The Internet and Higher Education, 4(3), 287-299.

18. Henderson, M., Bellis, N., Cerovac, M., \& Lancaster, G. (2013). Collaborative inquiry: building pre-service teachers' capacity for ICT pedagogical integration. Australian Educational Computing, 27(3), 69-75.

19. Hernandez, B., Montaner, T., Sese, F. J., \& Urquizu, P. (2011). The role of social motivations in e-learning: How do they affect usage and success of ICT interactive tools? Computers in Human Behavior, 27(6), 2224-2232.

20. InfoDev (2010). Information and Communication Technology for Education in India and South Asia, Essay III, Capacity Building for ICT in Education. Retrieved August 17, 2015, from http://www.infodev.org/infodev-files/resource/InfodevDocuments_888.pdf

21. Jordan, K. (2011). Framing ICT, teachers and learners in Australian school education ICT policy. The Australian Educational Researcher, 38(4), 417-431.

22. Jowi, J. O. (2009). Internationalization of higher education in Africa: Developments, emerging trends, issues and policy implications. Higher Education Policy, 22(3), 263-281.

23. Keengwe, J., Kidd, T., \& Kyei-Blankson, L. (2009). Faculty and technology: Implications for faculty training and technology leadership. Journal of Science Education and Technology, 18(1), 2328.

24. Kennedy, G. E., Judd, T. S., Churchward, A., Gray, K., \& Krause, K. L. (2008). First year students' experiences with technology: Are they really digital natives? Australasian joumal of educational technology, 24(1), 108-122.

25. Kozma, R. B., \& Voogt, J. (2003). Technology, innovation, and educational change: a global perspective: a report of the Second Information Technology in Education Study, Module 2. ISTE.

26. Kozma, R. B. (2005). National policies that connect ICT-based education reform to economic and social development. Human Technology: In an interdisciplinary journal on bumans in ICT environments, 1(2), 117-156. 
27. Kozma, R. B. (2008). Comparative analysis of policies for ICT in education. In J. Voogt \& G. Knezek (Eds.), International handbook of information technology in primary and secondary education (pp. 1083-1096). Springer.

28. Larson, R. C., \& Murray, M. E. (2008). Open Educational Resources for Blended Learning in High Schools: Overcoming Impediments in Developing Countries. Journal of Asynchronous Learning Networks, 12(1), 85-103.

29. Lloyd, M. M. (2008). Uncertainty and certainty: The visions and roadmaps of ICT educational policy. Computers in New Zealand Schools, 20(3), 13-21.

30. Marshall, G., \& Ruohonen, M. (Eds.). (1998). Capacity building for IT in education in developing countries. Springer Science \& Business Media.

31. Means, B., \& Olson, K. (1995). Technology's role in education reform: Findings from a national study of innovating schools. Washington, DC: U.S. Department of Education, Office of Educational Research and Improvement.

32. Ministry of Education (2008). ICT in Education Policy "Draft". Kigali: Government of Rwanda.

33. Nachmias, R., Mioduser, D., Cohen, A., Tubin, D., \& Forkosh-Baruch, A. (2004). Factors involved in the implementation of pedagogical innovations using technology. Education and Information Technologies, 9(3), 291-308.

34. Nichols, M. (2008). Institutional perspectives: The challenges of e-learning diffusion. British journal of educational technology, 39(4), 598-609.

35. Ojo, S., \& Awuah, B. (1998). Building resource capacity for IT education and training in schools: The case of Botswana. In G. Marshall \& M. Ruohonen (Eds.), Capacity building for IT in education in developing countries (pp. 27-38). Springer US.

36. Owens, T. (2012). Hitting the nail on the head: the importance of specific staff development for effective blended learning. Innovations in Education and Teaching International, 49(4), 389-400.

37. Owston, R. (2007). Contextual factors that sustain innovative pedagogical practice using technology: An international study. Journal of Educational Change, 8(1), 61-77.

38. Plessis, A., \& Webb, P. (2012). Teachers' Perceptions about their Own and their Schools' Readiness for Computer Implementation: A South African Case Study. Turkish Online Journal of Educational Technology-TOJET, 11(3), 312-325.

39. Phillips, D., \& Ochs, K. (2004). Researching policy borrowing: Some methodological challenges in comparative education. British Educational Research Journal, 30(6), 773-784.

40. Porter, W. W., Graham, C. R., Spring, K. A., \& Welch, K. R. (2014). Blended learning in higher education: Institutional adoption and implementation. Computers \& Education, 75, 185195.

41. Romeo, G., Lloyd, M., \& Downes, T. (2012). Teaching Teachers for the Future (TTF): Building the ICT in education capacity of the next generation of teachers in Australia. Australasian Journal of Educational Technology, 28(6), 949-964.

42. Salmon, G. (2005). Flying not flapping: a strategic framework for e-learning and pedagogical innovation in higher education institutions. Research in Learning Technology, 13(3), 201-218.

43. Siemens, G. (2014). Connectivism: A learning theory for the digital age. Retrieved from http://www.learningnetwork.ac.nz/shared/professionalReading/TRCONN2011.pdf 
44. Sife, A. S., Lwoga, E. T., \& Sanga, C. (2007). New Technologies for Teaching and Learning: Challenges for Higher Learning Institutions in Developing Countries. International Journal of Education and Development using Information and Communication Technology, 3(2). Retrieved from http://web.archive.org/web/20070705232755/http://ijedict.dec.uwi.edu/viewarticle.php?id $=246 \&$ layout $=\mathrm{html}$

45. Sun, P. C., Tsai, R. J., Finger, G., Chen, Y. Y., \& Yeh, D. (2008). What drives a successful e-Learning? An empirical investigation of the critical factors influencing learner satisfaction. Computers \& education, 50(4), 1183-1202.

46. Taguma, M. (2006). Quality of e-learning in tertiary education: Managing a balance between divergence and convergence. In U.-D. Ehlers \& J. M. Pawlowski (Eds.), Handbook on Quality and Standardisation in E-Learning (pp. 465-483). Springer Berlin Heidelberg.

47. Tanrikulu, Z., Tugcu, C., \& Yilmaz, S. (2010). E-University: Critical success factors. ProcediaSocial and Behavioral Sciences, 2(2), 1253-1259.

48. Taylor, J. A., \& Newton, D. (2012). Beyond blended learning: a case study of institutional change at an Australian regional university. The Internet and Higher Education, 18, 54-60.

49. Tondeur, J., Van Keer, H., van Braak, J., \& Valcke, M. (2008). ICT integration in the classroom: Challenging the potential of a school policy. Computers \& Education, 51(1), 212 223.

50. UNESCO (2011). UNESCO ICT Competency Framework for Teachers, Paris. Retrieved from http://unesdoc.unesco.org/images/0021/002134/213475e.pdf

51. Van Dijk, T. A. (1998). Ideology: A multidisciplinary approach. Sage.

52. Van Dijk, T. A. (2009). Critical discourse studies: A sociocognitive approach. Methods of critical discourse analysis, 2(1), 62-86.

53. Valcke, M. (2004). ICT in higher education: An uncomfortable zone for institutes and their policies. Beyond the comfort zone: Proceedings of the 21 ${ }^{\text {st }}$ ASCILITE Conference, 20-35.

54. Wodak, R., \& Meyer, M. (2009). Critical Discourse Studies: History, Agenda, Theory and Methodology. In R. Wodak \& M. Meyer (Eds.), Methods of Critical Discourse Analysis (Chapter 1). London: SAGE Publications.

\section{Acknowledgement}

The authors would like to acknowledge the Swedish International Development Cooperation Agency (SIDA) for financial support. Special thanks go to both the University of Rwanda and Stockholm University for supporting the research activities during this study with a high degree of collaboration during data collection process. 